\title{
Oil point and mechanical behaviour of oil palm kernels in linear compression**
}

\author{
Abraham Kabutey ${ }^{1 *}$,David Herak ${ }^{1}$, Rostislav Choteborsky², Čestmir Mizera ${ }^{1}$ \\ Riswanti Sigalingging ${ }^{3}$, and Olaosebikan Layi Akangbe ${ }^{1}$ \\ ${ }^{1}$ Department of Mechanical Engineering, ${ }^{2}$ Department of Material Sciences and Manufacturing Technology; \\ Czech University of Life Sciences Prague, Kamycka 129, Praha 6, Czech Republic \\ ${ }^{3}$ Department of Agricultural Engineering, University of Sumatera Utara, Prof. A. Sofyan 3, Kampus USU, Medan, Indonesia Republic
}

Received October 6, 2016; accepted May 29, 2017

\begin{abstract}
A b s t r a c t. The study described the oil point and mechanical properties of roasted and unroasted bulk oil palm kernels under compression loading. The literature information available is very limited. A universal compression testing machine and vessel diameter of $60 \mathrm{~mm}$ with a plunger were used by applying maximum force of $100 \mathrm{kN}$ and speed ranging from 5 to $25 \mathrm{~mm} \mathrm{~min}^{-1}$. The initial pressing height of the bulk kernels was measured at $40 \mathrm{~mm}$. The oil point was determined by a litmus test for each deformation level of $5,10,15,20$, and $25 \mathrm{~mm}$ at a minimum speed of $5 \mathrm{~mm}$ $\min ^{-1}$. The measured parameters were the deformation, deformation energy, oil yield, oil point strain and oil point pressure. Clearly, the roasted bulk kernels required less deformation energy compared to the unroasted kernels for recovering the kernel oil. However, both kernels were not permanently deformed. The average oil point strain was determined at 0.57 . The study is an essential contribution to pursuing innovative methods for processing palm kernel oil in rural areas of developing countries.

$\mathrm{K}$ e y w o r d s: bulk palm kernels, compression loading, deformation energy, oil point, percentage kernel oil
\end{abstract}

\section{INTRODUCTION}

The oil palm (Elaesis guineensis) is a tree crop originating from the tropical climates of West Africa. It requires a minimum rainfall of $1600 \mathrm{~mm}$ per year. After five years of cultivation, it starts to produce fruits bunches varying in weight from 10 to $75 \mathrm{~kg}$. The structure of the individual fruit consists of the exocarp (outer skin), mesocarp (a pulp containing the red palm oil), endocarp a central nut with the shell) and the kernel (holding the kernel oil similar to coconut oil) (FAO Agricultural services bulletin). Presently, Indonesia and Malaysia are major pro-

\footnotetext{
*Corresponding author e-mail: kabutey@tf.czu.cz

**This work was financially supported by the Internal Grant Agency of the Faculty of Engineering, CULS Prague, IGA 2016: 31130/1312/3106.
}

ducers of palm oil in the world (Chang et al., 2014; Lam et al., 2009; Owolarafe et al., 2007; Ozumba and Obiakor, 2011). Generally, the palm oil is used in packaged edible products including cooking oils, margarine, mayonnaise, ice cream, cookies and chocolates as well as non-edible products such as soaps, detergents and cosmetics. Palm kernel oil is also used in commercial cooking, which is relatively cheaper and has a longer storage period. It can also be used for the manufacture of soaps and washing powder. The meal is used as a fertiliser and livestock feed (Morrison and Heijndermans, 2013; Oriaku et al., 2013).

The mechanical oil extraction method is commonly used in developing countries due to its relatively lowcost and non-contaminated oil. However, the oil recovery efficiency is between 60 and 80\% (Chapius et al., 2014; Divisova et al., 2014; Khan and Hana, 1983). Solvent extraction, enzyme-assisted extraction and supercritical fluid extraction provide higher efficiency of oil recovery of $98 \%$. Nevertheless, the disadvantage is that they provide much complexity and higher cost for application in rural areas (Achten et al., 2007; Chen et al., 2012; Subroto et al., 2015a,b). For the palm oil processing, the fresh fruit bunch undergoes sterilisation, striping, and digestion, leaving shelled palm nuts and fibres. The nuts are cracked to produce palm kernels and shells. Palm kernels are further processed to yield palm kernel oil. From the traditional point of view, the processing of palm kernel oil is energy -intensive and time-consuming as it involves drying of nuts, cracking of nuts, sieving of cracked nuts, separation of ker-

(C) 2017 Institute of Agrophysics, Polish Academy of Sciences 
nels, sun-drying of kernels, winnowing of kernels, removal of undesired materials, roasting of kernels, milling of roasted kernels into paste and cooking and, finally, collection of oil. The kernel cake or meal is a by-product.

In the literature, there is very limited information on compression loading test of oil palm kernels (Akinoso et al., 2009; Akinoso and Raji, 2011; Ozumba and Obiakor, 2011). The studies available, however, mainly focused on the effects of compressive force, speed, temperature, moisture content and loading positions of single or bulk kernels by evaluating the rupture force, deformation, energy and toughness. For instance, Ozumba and Obiakor (2011) indicated that rupture force of single palm kernels at vertical position increased from 181.23 to $208.60 \mathrm{~N}$ as moisture content increased from 5 to $10 \%$ w.b. while at the horizontal position, it increased up to $7 \%$ w.b. and then decreased at $10 \%$ w.b. However, at both horizontal and vertical positions, the rupture force first increased and then decreased as temperature increased from 70 to $110^{\circ} \mathrm{C}$. Akinoso and Raji (2011) also reported that the force and energy of Tenera and Dura varieties of single palm kernels decreased with increased moisture content between 5 and $11 \%$ w.b. and temperature between 40 and $80^{\circ} \mathrm{C}$. The deformation, on the other hand, increased for Tenera but decreased for Dura in relation to moisture content and temperature as already indicated above. For the bulk oil palm kernels under compression loading, our previously published studies indicated that a slight change in deformation of heat-treated or roasted bulk kernels was observed at a force of $100 \mathrm{kN}$ and a speed of $60 \mathrm{~mm} \mathrm{~min}{ }^{-1}$ (Kabutey et al., 2013). In addition, an optimal pressing force of $250 \mathrm{kN}$ at a speed of $10 \mathrm{~mm} \mathrm{~min}^{-1}$ for maximum kernel oil was noticed after three repeated loadings of both roasted and unroasted bulk oil palm kernels (Kabutey et al., 2016a).

In the industrial practice, however, optimization of the mechanical oil extraction has been also centred on process parameters namely pressure, feeding rate, speed of rotation, temperature, pressing time, moisture content, size reduction and heat treatment (Akinoso et al., 2006, 2009; Deli et al., 2011; Karaj and Muller, 2011; Ogunsina et al., 2008). Akinoso et al. (2009) especially reported that maximum oil yield of $46.3 \%$ was found at a compressive stress of $30 \mathrm{MPa}$, feed rate of $150 \mathrm{~kg} \mathrm{~h}^{-1}$ and rotational speed of 110 r.p.m. while minimum oil yield of $16.3 \%$ was obtained at $10 \mathrm{MPa}$ compressive stress, $50 \mathrm{~kg} \mathrm{~h}^{-1}$ feed rate and 110 r.p.m. of rotational speed employing the expeller Tite 002 (Tiny Plant, Rajkot, India) with $180 \mathrm{~kg} \mathrm{~h}^{-1}$ throughput and power of $30 \mathrm{~kW}$ electric motor with interchangeable speed.

The concept of oil point pressure also provides relevant information for design and performance evaluation of mechanical oil expellers or presses (Mrema and McNulty, 1985; Ogunsina et al., 2008). The oil point is the stage at which the oilseed has been adequately squeezed onto the surface of the seeds which is theoretically related to the kernel density of the oilseed (Faborade and Favier, 1996). The present study is a further continuation of our previously published studies, and now the objectives were to determine the oil point pressure with the corresponding strain and the mechanical properties namely the deformation $\mathrm{mm}$, deformation energy $(\mathrm{J})$ and oil yield (\%) of roasted and unroasted oil palm kernels in relation to varying speeds under compression loading.

\section{MATERIALS AND METHOD}

Samples of roasted and unroasted oil palm kernels were brought from New Tafo in the Eastern Region of Ghana. The standard oven method with a temperature setting of $105^{\circ} \mathrm{C}$ and a drying time of $17 \mathrm{~h}$ was used for the moisture content determination (ISI, 1996). The initial mass of the samples before and after oven drying was weighed using an electronic balance (Kern 440-35, Kern and Sohn GmbH, Balingen, Germany) with an accuracy of $0.001 \mathrm{~g}$. The test was repeated thrice and the results were averaged. Using Eq. (1) given by Blahovec (2008), the moisture content of roasted and unroasted oil palm kernels was determined as $3.33 \pm 0.19 \%$ w.b. and $9.67 \pm 0.196 \%$ w.b., respectively.

$$
M C=\left[\left(\frac{m_{a}-m_{b}}{m_{a}}\right) 100\right],
$$

where: $M C$ is the percentage moisture content on wet basis (\% w.b.), $m_{a}$ and $m_{b}$ are the masses of samples before and after heat treatment $(\mathrm{g})$. A compression testing machine (ZDM 50, Czech Republic) and a pressing vessel of diameter $60 \mathrm{~mm}$ with a $170 \mathrm{~mm}$ long plunger were used for the test by applying a maximum compressive force of $100 \mathrm{kN}$ and speed ranging from 5 to $25 \mathrm{~mm} \mathrm{~min}^{-1}$. The initial pressing height of the bulk kernels was $40 \mathrm{~mm}$. The oil point of the bulk kernels defined as the first drop of oil was determined by a litmus test for each deformation values of $5,10,15,20$, and $25 \mathrm{~mm}$ at a minimum speed of $5 \mathrm{~mm}$ $\min ^{-1}$ (Faborade and Favier, 1996; Herak et al., 2013; ). The percentage oil yield was determined by Eq. (2) (Deli et al., 2011; Kabutey et al., 2015).

$$
O_{y}=\left[\left(\frac{O_{w}}{O_{m}}\right) 100\right],
$$

where: $O_{y}$ is the percentage oil yield, $O_{w}$ is the mass of kernel oil (g), and $O_{m}$ is the mass of initial pressing height of kernels $(\mathrm{g})$. The mass of kernel oil $O_{w}$ was calculated as the difference between the mass of initial height of kernels $O_{m}$ and the mass of kernel cake. The deformation energy of the kernels was numerically determined by Eq. (3) (Herak et al., 2012): 


$$
E=\sum_{n=0}^{n=i=1}\left[\left(\frac{F_{n+1}+F_{n}}{2}\right)\left(x_{n+1}-x_{n}\right)\right],
$$

where: $E$ is the deformation energy (J), $F_{n+1}+F_{n}$ and $x_{n+1}$ $-x_{n}$ are the compressive force $(\mathrm{N})$ and deformation $(\mathrm{mm})$, $n$ is the number of data points and $i$ indicates the number of sections of axis deformation. The oil point pressure of the bulk kernel was calculated using Eq. (4) (Kabutey et al., 2016b):

$$
P_{o p t}=\frac{F}{A},
$$

where: $P_{\text {opt }}$ is the oil point pressure $\left(\mathrm{N} \mathrm{mm}^{-2}\right.$ equal to $\left.\mathrm{MPa}\right)$, $F$ is the compressive force (N), and $A$ is the cross-sectional area of the pressing vessel $\left(\mathrm{mm}^{2}\right)$. The oil point strain was also calculated applying Eq. (5) (Herak et al., 2010).

$$
\varepsilon_{\text {opt }}=\frac{X_{d L}}{H},
$$

where: $\varepsilon_{o p t}$ is the oil point strain, $X_{d l}$ is the deformation level of bulk kernel (mm) and $H$ is the initial height of bulk kernel $(\mathrm{mm})$. The data obtained was a repetition of two compression tests subjected to ANOVA analysis performed by employing STATISTICA 13 software (Statsoft, 2013).

\section{RESULTS AND DISCUSSION}

The determined amounts of roasted and unroasted oil palm kernels and their statistical evaluation are shown in Tables 1 and 2 . The results were statistically significant at $\mathrm{p}<0.05$ or $\mathrm{F}>\mathrm{F}_{\text {crit }}$ with very high coefficients of determina- tion $\mathrm{R}^{2}=0.99$ (Table 2). This explains that the compression speed influenced the values of deformation $(\mathrm{mm})$, energy (J) and oil yield (\%) of both bulk kernels. Clearly, for roasted kernels, the amounts of deformation, energy and oil yield in relation to the different speeds ranged from 23.67 \pm 0.03 to $22.82 \pm 0.18 \mathrm{~mm}, 488.79 \pm 1.71$ to $416.20 \pm 0.14 \mathrm{~J}$ and $15.24 \pm 0.04$ to $10.85 \pm 0.14 \%$ while that of unroasted kernels ranged from $23.83 \pm 0.23$ to $24.05 \pm 0.09 \mathrm{~mm}$, $553.43 \pm 0.17$ to $513.16 \pm 0.41 \mathrm{~J}$ and $22.79 \pm 0.37$ to 18.32 $\pm 0.48 \%$, respectively. The percentage oil yield and energy of unroasted kernels were higher than those of roasted kernels, which could partly be due to the higher moisture content. Moreover, at the minimum speed of $5 \mathrm{~mm} \mathrm{~min}^{-1}$, the highest oil yield was observed (Table 1). This means that at a higher speed the processing time for the oil flow from the solids is reduced. The input pressure or compressive stress also determines the oil processing time and energy demand for maximum oil recovery (Akinoso et al., 2009; Karaj and Muller, 2011; Kabutey et al., 2015). Considering the energy-intensive and time-consuming nature of the traditional oil processing of roasted kernels, direct processing of unroasted kernels would be less labour intensive and more environmentally friendly. Therefore, identifying the suitable compression speed and pressure for processing unroasted bulk oil palm kernels is vital for the design and development of optimal processing technology.

The force-deformation curves of unroasted oil palm kernels in relation to speeds similar to roasted kernels are displayed in Fig. 1. The behaviour of the force-deformation curves is useful for the description of the oil point threshold as well as the optimal energy for the oil recovery. No curves

T a b l e 1. Measured parameters of roasted and unroasted bulk kernels at force $100 \mathrm{kN}$ for different speeds

\begin{tabular}{cccc}
\hline Speed $\left(\mathrm{mm} \mathrm{min}^{-1}\right)$ & Deformation $(\mathrm{mm})$ & Energy $(\mathrm{J})$ & Oil yield $(\%)$ \\
\hline & \multicolumn{2}{c}{ Roasted kernels } & \\
5 & $23.67 \pm 0.03$ & $488.79 \pm 1.71$ & $15.24 \pm 0.04$ \\
10 & $24.07 \pm 0.07$ & $462.48 \pm 0.27$ & $12.93 \pm 0.08$ \\
15 & $23.31 \pm 0.26$ & $440.51 \pm 0.50$ & $11.56 \pm 0.06$ \\
20 & $22.93 \pm 0.09$ & $414.52 \pm 0.51$ & $10.85 \pm 0.06$ \\
25 & $22.82 \pm 0.18$ & $416.20 \pm 0.14$ & $22.79 \pm 0.37$ \\
5 & & & $20.45 \pm 0.64$ \\
10 & $23.83 \pm 0.23$ & $553.43 \pm 0.17$ & $19.81 \pm 0.17$ \\
20 & $22.51 \pm 0.38$ & $530.77 \pm 0.07$ & $19.33 \pm 0.06$ \\
25 & $24.09 \pm 0.21$ & $530.35 \pm 0.31$ & $18.32 \pm 0.48$
\end{tabular}


T a b l e 2. ANOVA analysis of measured parameters of roasted and unroasted bulk oil palm kernels

\begin{tabular}{|c|c|c|c|c|c|c|c|c|}
\hline \multirow{2}{*}{ Parameters } & \multicolumn{4}{|c|}{ Roasted kernels } & \multicolumn{4}{|c|}{ Unroasted kernels } \\
\hline & $\mathrm{R}^{2}$ & F & $\mathrm{F}_{\text {crit }}$ & $\mathrm{p}$-value & $\mathrm{R}^{2}$ & F & $\mathrm{F}_{\text {crit }}$ & $\mathrm{p}$-value \\
\hline Deformation (mm) & 0.97 & 22.17 & 2.246 & $<0.05$ & 0.96 & 17.08 & 2.246 & $<0.05$ \\
\hline Energy $(\mathrm{J})$ & 0.99 & 2822.90 & 2.246 & $<0.05$ & 0.99 & 5877.49 & 2.246 & $<0.05$ \\
\hline Oil yield (\%) & 0.99 & 867.48 & 2.246 & $<0.05$ & 0.98 & 34.16 & 2.246 & $<0.05$ \\
\hline
\end{tabular}

$\mathrm{p}<0.05$ or $\mathrm{F}>\mathrm{F}_{\text {crit }}$ means significant.

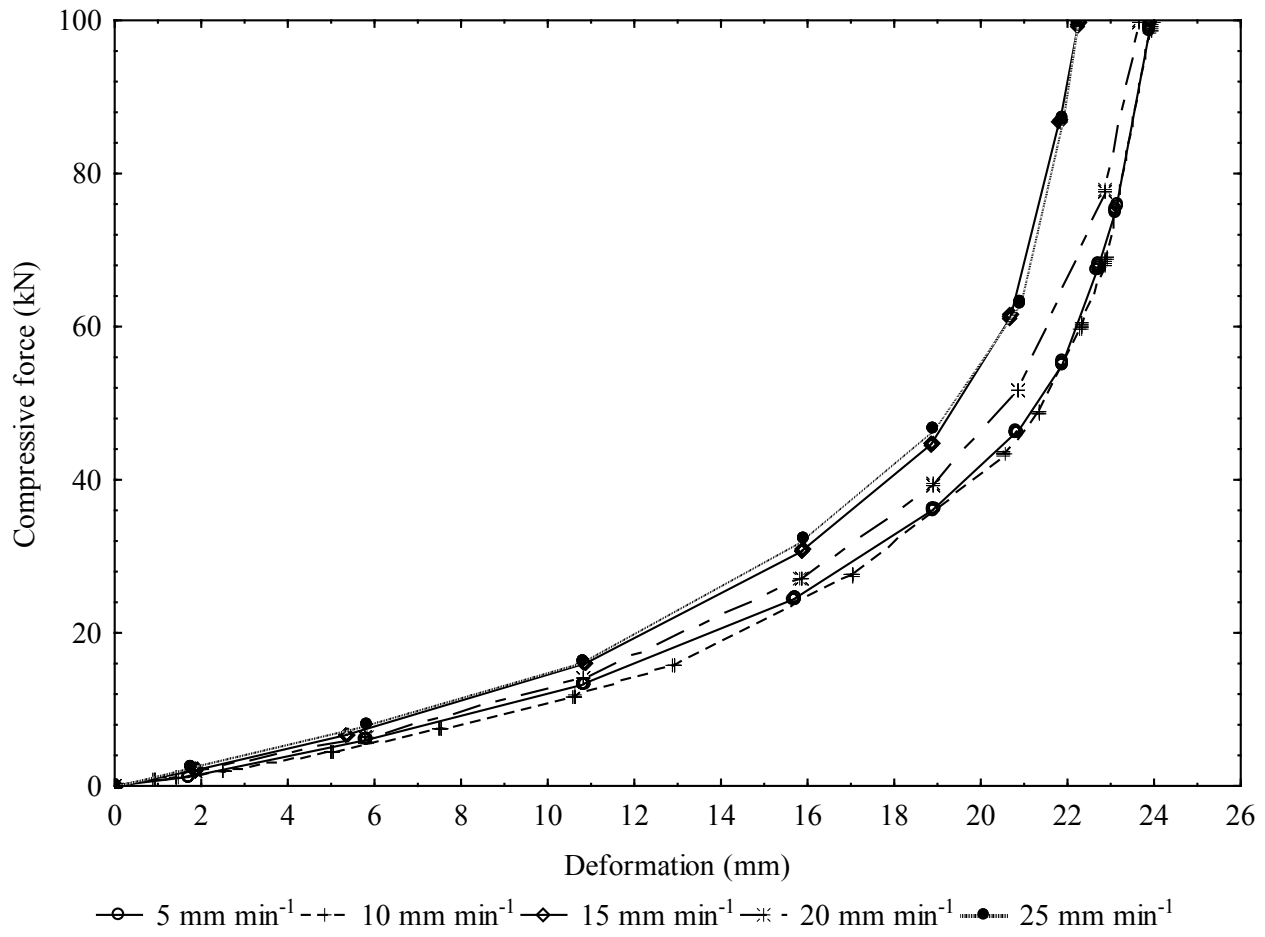

Fig. 1. Dependency between compressive force and deformation curves of bulk unroasted kernels in relation to different speed, similar to roasted bulk kernels.

showed any serration characteristics, which is mostly caused by the higher moisture content, compressive force and diameter of the pressing vessel (Divisova et al., 2014).

The amounts of oil point pressure and strain are indicated in Table 3. These parameters were calculated using Eqs (4) and (5), respectively. The lower and upper oil points were observed at deformation levels of 20 and $25 \mathrm{~mm}$ with corresponding strain values of 0.5 and 0.63 of an average value of 0.57 (Fig. 2). The lower and upper oil points pressure of roasted kernels ranged from $10.08 \pm 0.05$ to 20.19 $\pm 0.06 \mathrm{MPa}$ while that of the unroasted ones ranged from $10.09 \pm 0.05$ to $26.60 \pm 0.14 \mathrm{MPa}$. The average values were $15.14 \pm 0.06$ and $18.35 \pm 0.10$. In the literature, the average oil point strain of some selected oilseeds or kernels of jatropha, melon, rapeseed, cashew, soybean and oil palm has been reported (Sukumaran and Singh, 1989; Faborade and
Favier, 1996; Raji and Favier, 2004; Ogunsina et al., 2008; Herak et al., 2013). The values ranged between 0.38 to 0.69 at a moisture content between 4.3 and $8.5 \%$ w.b. For oil point pressure, it can be seen that roasted kernels showed a smaller amount compared to the unroasted ones, which explains the positive effect of heat treatment on oil flow from the oil-bearing cells. On the contrary, the higher oil point pressure of unroasted kernels could also be attributed to the high moisture content. Ogunsina et al. (2008) and Tunde-Akintunde (2008) have indicated that oil point pressure increases with an increase in moisture content. For instance, oil point pressure of $0.157 \mathrm{MPa}$ was found for fine cashew kernel at a moisture content of $4 \%$ w.b. while $0.166 \mathrm{MPa}$ was recorded for coarse cashew kernel at a moisture content of $6 \%$ w.b. Clearly, at higher moisture levels, the cushioning effect of mucilage develops, and this 
T a b l e 3. Oil point strain and pressure of roasted and unroasted bulk kernels at speed $5 \mathrm{~mm} \mathrm{~min}^{-1}$

\begin{tabular}{cccc}
\hline \multirow{2}{*}{$\begin{array}{c}\text { Oil point } \\
\text { deformation level } \\
(\mathrm{mm})\end{array}$} & Oil point strain & roasted kernels & Oil point pressure (MPa) \\
\cline { 3 - 4 } 20 & $0.50 \pm 0.00 \mathrm{a}$ & $10.08 \pm 0.05$ & $10.09 \pm 0.05$ \\
25 & $0.63 \pm 0.00 \mathrm{~b}$ & $20.19 \pm 0.06$ & $26.60 \pm 0.14$ \\
Average & $0.57 \pm 0.00$ & $15.14 \pm 0.06$ & $18.35 \pm 0.10$ \\
\hline
\end{tabular}

a, b - lower and upper oil points of bulk kernels of initial pressing height $40 \mathrm{~mm}$.

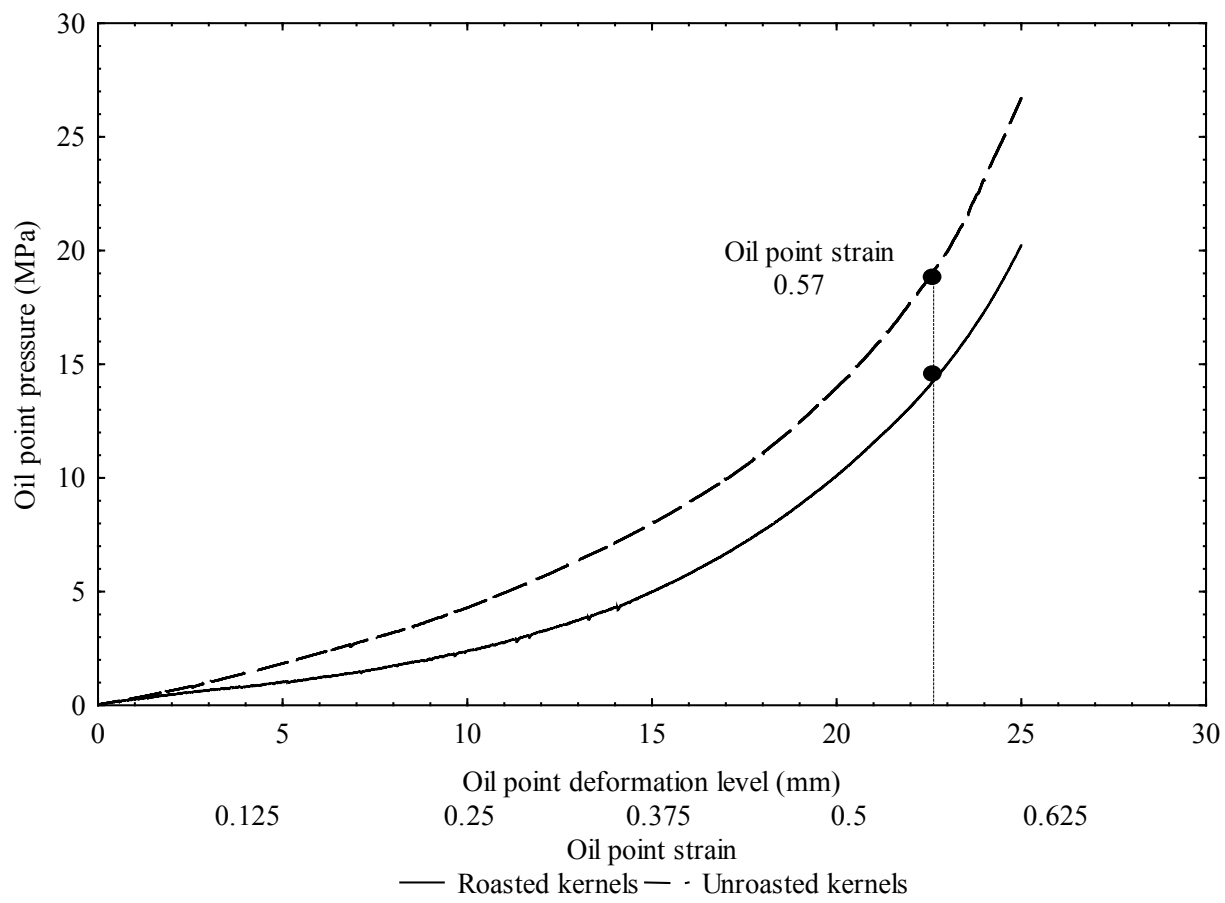

Fig. 2. Oil point pressure versus deformation level and strain of bulk roasted and unroasted kernels at pressing height $40 \mathrm{~mm}$ and speed $5 \mathrm{~mm} \mathrm{~min} \mathrm{~m}^{-1}$.

mucilage consumes energy generated by the pressure to compress the oil out of the oil-bearing cells thus increasing the oil point pressure (Ajibola et al., 2002). In this study, the average oil point strain of both kernels was higher in comparison with the findings of some of the above-mentioned authors. The reason could be related to the variation in the structural integrity of the oil bearing materials, that is, the change in the physical (moisture content, initial bulk density, kernel density, porosity) and mechanical (contact and gradient pressure and compressibility) properties.

\section{CONCLUSIONS}

1. The average oil point strain of roasted and unroasted oil palm kernels was observed at 0.57 with corresponding oil point pressure of $15.14 \pm 0.06$ and $18.35 \pm 0.10$, respectively.
2. Roasted kernels required less deformation energy than unroasted kernels for recovering the kernel oil in relation to the various speeds between 5 and $25 \mathrm{~mm} \mathrm{~min}^{-1}$.

3 . The bulk kernels were not permanently deformed at a maximum force of $100 \mathrm{kN}$ confirming previous findings that a repeated compression or a higher force would be needed to obtain greater percentage kernel oil.

4. There was no serration effect or undulation behaviour on the force-deformation curves in relation to the different speeds.

5. Identifying the specific compressive force, speed, oil point pressure and strain among other indicators is vital for the design and development of optimal processing technology.

Conflict of interest: The Authors do not declare conflict of interest. 


\section{REFERENCES}

Achten W.M.J., Mathijs E., Verchot L., Singh V.P., Aerts R., and Muys B., 2007. Jatropha biodiesel fueling sustainability? Biofuels Bioprod. Biorefining, 1, 283-291.

Ajibola O.O., Okunade D.A., and Owolarafe O.K., 2002. Oil point pressure of soybean. J. Food Process Eng., 25, 407-416.

Akinoso R. and Raji A.O., 2011. Physical properties of fruit, nut and kernel of oil palm. Int. Agrophys., 25, 85-88.

Akinoso R., Raji A.O., and Igbeka J.C., 2009. Effects of compressive stress, feeding rate and speed on palm kernel oil yield. J. Food Eng., 93, 427-430.

Blahovec J., 2008. Agromaterials-Study Guide. Czech University of Life Sciences Prague, 7-8.

Chang S.K., Ismail A., Yanagita T., Esa N.M., and Baharuldin M.T.H., 2014. Biochemical characterisation of the soluble proteins, protein isolates and hydrolysates from oil palm (Elaeis guineensis) kernel. Food Bioscience, 7, 1-10.

Chapuis A., Blin J., and Lecomte D., 2014. Separation efficiency and energy consumption of oil expression using a screwpress: The case of Jatropha curcas L. seeds. Industrial Crops Products, 52, 752-761.

Chen C.R., Cheng Y.J., Ching Y.C., Hsiang D., and Chang C.M.J., 2012. Green production of energetic Jatropha oil from deshelled Jatropha curcas L. seeds using supercritical carbon dioxide extraction. J. Supercrit. Fluids, 66, 137-143.

Deli S., Farah Masturah M., Tajul Aris Y., and Wan Nadiah W. A., 2011. The effects of physical parameters of the screw press oil expeller on oil yield from Nigella sativa L. seeds. Int. Food Research, 18, 1367-1373.

Divisova M., Herak D., Kabutey A., Sleger V., Sigalingging R., and Svatonova T., 2014. Deformation curve characteristics of rapeseeds and sunflower seeds under compression loading. Scientia Agriculturae Bohemicae, 45(3), 180-186.

Faborade M.O. and Favier J.F., 1996. Identification and significance of the oil-point in seed-oil expression. J. Agric. Eng. Res., 65, 335-345.

FAO Agricultural Services Bulletin, 2002. Small-scale palm oil processing in Africa, 148, pp. 1-59.

Herak D., Gurdil G., Sedlacek A., Dajbych O., and Simanjuntak S., 2010. Energy demands for pressing Jatropha curcas L. seeds. Biosystems Engineering, 106(4), 527-534.

Herak D., Kabutey A., and Hrabe P., 2013. Oil point determination of Jatropha curcas L. bulk seeds under compression loading. Biosystems Eng., 116(4), 470-477.

Herak D., Kabutey A., Sedláček A., and Gürdil G., 2012. Mechanical behaviour of several layers of selected plant seeds under compression loading. Research Agric. Eng., 58(1), 24-29.

ISI, 1966. Indian standard methods for analysis of oilseeds, IS: 3579. Indian Standard Institute, New Delhi, India.

Kabutey A., Divisova M., Sedlacek L., Boatri W.E., Svatonova T., and Sigalingging R., 2013. Mechanical behaviour of oil palm kernels (Elaeis guineensis). Scientia Agriculturae Bohemica, 44, 18-22.

Kabutey A., Herák D., Chotěborský R., Sigalingging R., and

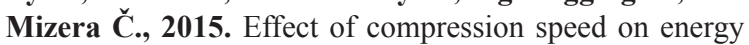
requirement and oil yield of Jatropha curcas L. bulk seeds under linear compression. Biosystems Eng., 136, 8-13.
Kabutey A., Herak D., Dajbych O., Akangbe O.L., Napitupulu R., and Pandiangan S., 2016a. Mechanical behaviour of roasted and unroasted oil palm kernels under compression loading. Proc. Int. Symp. Mechanical and Agricultural Engineering, ISB-INMA TEH, October 27-29, Bucharest, Romania.

Kabutey A., Herak D., Hanus J., Choteborsky R., Dajbych O., Sigalingging R., and Akangbe O.L., 2016b. Prediction of pressure and energy requirement of Jatropha curcas L. bulk seeds under non-linear pressing. Proc. VI Int. Conf. Trends in Agricultural Engineering TAE, September 7-9, CULS Prague, Prague, Czech Republic.

Karaj S. and Muller J., 2011. Optimizing mechanical oil extraction of Jatropha curcas L. seeds with respect to press capacity, oil recovery and energy efficiency. Industrial Crops and Products, 34, 1010-1016.

Khan L.M. and Hanna M.A., 1983. Expression of oil from oilseeds - a review. Agric. Eng. Res., 28, 495-503.

Lam M.K., Tan K.T., Lee K.T., and Mohamed A.R., 2009. Malaysian palm oil: Surviving the food versus fuel dispute for a sustainable future. Renewable and Sustainable Energy Review, 13, 1456-1464.

Morrison A.K. and Heijndermans E., 2013. Palm Kernel Oil Production Process Characterization, An Energy, Poverty and Gender (EnPoGen) Initiative of SNV Ghana, 1-47.

Mrema G.C. and McNulty P.B., 1985. Mathematical model of mechanical oil expression from oilseeds. Agric. Eng. Res., 31, 361-370.

Ogunsina B.S., Owolarafe O.K., and Olatunde G.A., 2008. Oil point pressure of cashew (Anacardium occidentale) kernels. Int. Agrophysics, 22, 53-59.

Oriaku E.C., Agulanna C.N., Edeh J.C., and Nwannewuihe H.U., 2013. Determination of optimal angle of projection and separation of palm nut shell and kernel using a designed cracker/separator machine. Int. J. Sci. Tech. Res., 2(10), 289-292.

Oworlarafe O.K., Olabige M.T., and Faborade M.O., 2007. Physical and mechanical properties of two varieties of fresh oil palm fruit. J. Food Eng., 78, 1228-1232.

Ozumba I.C. and Obiakor S.I., 2011. Fracture resistance of palm kernel seed to compressive loading. J. Stored Products and Postharvest Res., 2(13), 248-253.

Raji A.O. and Favier J.V., 2004. Model for the deformation in agricultural and food particulate materials under bulk compressive loading using discrete element method II: Compression of oil seeds. J. Food Eng., 64, 373-380.

Statsoft, 2013. Inc. Tulsa, OK74104, USA.

Subroto E., Manurung R., Heeres H.J., and Broekhuis A.A., 2015a. Optimization of mechanical oil extraction of Jatropha curcas L. kernel using response surface method. Industrial Crops and Products, 63, 294-302.

Subroto E., Manurung R., Heeres H.J., and Broekhuis A.A., 2015b. Mechanical extraction of oil from Jatropha curcas L. kernel: Effect of processing parameters. Industrial Crops and Products, 63, 303-310.

Sukumaran C.R. and Singh B., 1989. Compression of a bed of rapeseeds - the oil-point. J. Agric. Eng. Res., 42, 77-84.

Tunde-Akintunde T.Y., 2008. Determination of oil point pressure for melon seeds. J. Food Process Eng., 33,179-189. 